Published in final edited form as:

Magn Reson Med. 2016 July ; 76(1): 270-281. doi:10.1002/mrm.25875.

\title{
Quantitative theory for the longitudinal relaxation time of blood water
}

\author{
Wenbo $\mathbf{L i}^{1,2, \dagger}$, Ksenija Grgac ${ }^{1,2, \dagger}$, Alan Huang ${ }^{1,2,3}$, Nirbhay Yadav $^{1,2}$, Qin Qin ${ }^{1,2}$, and Peter \\ C.M. van $\mathrm{Zijl}{ }^{*}, 1,2$
}

${ }^{1}$ Department of Radiology, Johns Hopkins University School of Medicine, Baltimore, Maryland ${ }^{2}$ F.M. Kirby Research Center for Functional Brain Imaging, Kennedy Krieger Institute, Baltimore, Maryland

\section{Abstract \\ Purpose-To propose and evaluate a model for the blood water $\mathrm{T}_{1}$ that takes into account the effects of hematocrit fraction, oxygenation fraction, erythrocyte hemoglobin concentration, methemoglobin fraction and plasma albumin concentration.}

Methods-Whole blood and lysed blood $\mathrm{T}_{1}$ data were acquired at magnetic fields of 3T, 7T, 9.4T and 11.7T using inversion-recovery measurements and a home-built blood circulation system for maintaining physiological conditions. A quantitative model was derived based on multi-variable fitting of this data.

Results-Fitting of the model to the data allowed determination of the different parameters describing the blood water $T_{1}$ such as those for the diamagnetic and paramagnetic effects of albumin and hemoglobin, and the contribution of methemoglobin. The model correctly predicts blood $\mathrm{T}_{1}$ at multiple fields, as verified by comparison with existing literature.

Conclusion-The model provides physical and physiological parameters describing the effects of hematocrit fraction, oxygenation, hemoglobin concentration, methemoglobin fraction and albumin concentration on blood water $\mathrm{T}_{1}$. It can be used to predict blood $\mathrm{T}_{1}$ at multiple fields.

\section{Keywords}

longitudinal relaxation; in vitro blood; hematocrit; oxygenation; hemoglobin concentration; methemoglobin; albumin; relaxivity; $\mathrm{T}_{1}$ model

\section{Introduction}

The longitudinal relaxation rate $\left(\mathrm{R}_{1}=1 / \mathrm{T}_{1}\right)$ of water proton in blood plays an important role in various quantitative MRI applications, such as measuring cerebral blood flow using

\footnotetext{
*Correspondence: Peter C.M. van Zijl, PhD, F. M. Kirby Research Center for Functional Brain Imaging, The Kennedy Krieger Institute, 707 N. Broadway, Room G-25, Baltimore, MD, 21205, United States of America, pvanzij1@mri.jhu.edu, Tel: 443-923-9500, Fax: 443-923-9505.

†These authors contributed equally to this work.

${ }^{3}$ Current address: Philips Healthcare, Best, The Netherlands
} 
arterial spin labeling (1) as well as determining the appropriate nulling point for black blood imaging (2) and vascular space occupancy (VASO) MRI, a cerebral blood volume weighted functional MRI approach (3). It is also a valuable diagnostic parameter for staging hematoma $(4,5)$.

Under physiological conditions, blood is composed mainly of plasma and erythrocytes with the erythrocyte volume fraction referred as hematocrit fraction (Hct). The intracellular volume of erythrocyte consists mainly of a high concentration ( $\sim 5 \mathrm{mM}$ tetramer) hemoglobin solution. Regular hemoglobin with $\mathrm{Fe}^{2+}$ in the heme is a diamagnetic protein when binding $\mathrm{O}_{2}\left(\mathrm{HbO}_{2}\right)$, but paramagnetic when not coordinated to $\mathrm{O}_{2}$ (deoxyHb). Methemoglobin $(\mathrm{MetHb})$ with $\mathrm{Fe}^{3+}$ in the heme, which is a trace amount in physiological blood but has high concentration in methemoglobinemia $(6,7)$ and aged blood such as hematoma (4), is also paramagnetic with high relaxivity. In terms of water ${ }^{1} \mathrm{H}$ magnetic properties at a certain magnetic field, blood can be considered as consisting of two water compartments separated by the erythrocyte membrane: (i) the plasma, characterized by a constant water $\mathrm{T}_{1}$ depending on the albumin concentration, and (ii) the erythrocyte cytoplasm characterized by a water $\mathrm{T}_{1}$ depending on the hemoglobin concentration in the erythrocyte (mean corpuscular hemoglobin concentration, MCHC), methemoglobin fraction ( $\mathrm{f}_{\mathrm{MetHb}}$ ) and oxygenation fraction (Y). The hemoglobin concentration in the erythrocyte and the albumin concentration in the plasma determine the water fractions in these two compartments.

To date, the longitudinal relaxation rate of water in blood has been measured in vivo and in vitro at multiple magnetic fields, showing a linear dependence of longitudinal relaxation rate $\mathrm{R}_{1}=1 / \mathrm{T}_{1}$ on Hct, and $\mathrm{Y}(8-29)$. Several calibration equations $(14,17,19,20,23,26-29)$ have been derived as a function of hematocrit fraction (Hct) and oxygenation fraction (Y). In addition to these two parameters, $\mathrm{R}_{1}$ depends on the hemoglobin concentration in erythrocytes (MCHC), which is generally constant under physiological conditions (30), but may vary under pathological situations. The methemoglobin fraction ( $\left.\mathrm{f}_{\mathrm{MetHb}}\right)$ may also greatly affect $R_{1}$, but this effect was previously measured only at magnetic fields below $3 \mathrm{~T}$ $(13,31-37)$. Therefore, we measured a series of lysed and whole blood water $T_{1}$ data and derived and evaluated a general theory that describes the effects of Hct, Y, MCHC and $f_{\text {MetHb }}$ on blood water $R_{1}$ at higher magnetic fields ( $23 T$ ).

\section{METHODS}

\section{Sample Preparation}

Bovine blood, an analogue of human blood with similar hemoglobin structure (38), erythrocyte permeability (39), MCHC (40) and viscosity (40), was obtained from a local slaughterhouse. Fresh blood (3.5L) was mixed with $300 \mathrm{~mL} 83 \mathrm{mM}$ sodium citrate solution to prevent coagulation. The samples were stored at $4^{\circ} \mathrm{C}$, and used within 8 days. Samples with different hematocrit fractions were prepared by centrifuging blood samples and separating them into erythrocytes and plasma at $10,000 \mathrm{G}$ for $15 \mathrm{~min}$ at $4^{\circ} \mathrm{C}$, and recombining them in appropriate volume ratios. The lysed blood samples with different hemoglobin concentrations were prepared through lysing the whole blood with target hemoglobin concentration by sonication (Branson Ultrasonics, Danbury, CT) on ice for 6min with 45\% amplitude and 10s "on", $5 \mathrm{~s}$ "off" working cycles. The cell lysate after centrifugation 
$\left(10,000 \mathrm{G}, 15 \mathrm{~min}\right.$ at $\left.4^{\circ} \mathrm{C}\right)$ was immediately used for $\mathrm{T}_{1}$ measurements. For the experiments to determine methemoglobin's relaxivity, concentrated sodium nitrite solution $(23 \mathrm{mM})$ was added into fully oxygenated lysed blood and equilibrated at room temperature for 2 hours to prepare samples with different methemoglobin concentrations (1 mole sodium nitrite can roughly transfer 1 mole hemoglobin to methemoglobin). The phosphate buffered saline (PBS) solution was prepared by diluting 10 times in PBS liquid (Fisher) with deionizing water.

A home-built blood circulation system $(14,17,41)$ was used to prevent sedimentation of erythrocytes, and to control temperature and oxygenation fraction. Temperature was maintained at $37+/-0.3^{\circ} \mathrm{C}$ for all experiments. Oxygenation was controlled by blowing $\mathrm{N}_{2} / \mathrm{O}_{2}$ mixture into the mixing chamber in the blood circulation system and measured in the flow system using a fiber-optic $\mathrm{pO}_{2}$ sensor (Oxford Optronix) placed outside the coil. Whole or lysed blood samples were circulated with a flowing speed of $\sim 30 \mathrm{~mL} / \mathrm{min}(\sim 0.5 \mathrm{~cm} / \mathrm{s})$. During experiments, we used a flow-stop-flow pattern, i.e. a flowing blood sample for the first 5-10 seconds, after which the flow was stopped 5-10 seconds before MR signal acquisition and resumed after acquisition. This strategy prevented erythrocyte precipitation and "washout" effects during $\mathrm{T}_{1}$ measurement. A cylinder sample tube (inner diameter 11 $\mathrm{mm}$ ) was connected with the circulation system at both ends, and positioned vertically inside the RF coil. Experiments for determination of methemoglobin's relaxivity and water $T_{1}$ in saline solution were performed in a tube not connected to the perfusion system. Samples were equilibrated in the $37.5^{\circ} \mathrm{C}$ water bath for $20 \mathrm{~min}$, and then quickly put into the magnet for $\mathrm{T}_{1}$ experiments $(5-10 \mathrm{~min})$. Sample temperatures after experiments were measured as $36.5-37.0^{\circ} \mathrm{C}$.

During the experiment, the $\mathrm{O}_{2}$ needs to be carefully controlled because the free $\mathrm{O}_{2}$ dissolved in the blood can decrease $T_{1}$ as reported before $(14,28,42)$. In venous blood samples, the $\mathrm{pO}_{2}$ is tightly related to $\mathrm{Y}$ following the oxygen-hemoglobin dissociation curve, but for arterial blood more free $\mathrm{O}_{2}$ will be present at higher $\mathrm{pO}_{2}$, leading to a reduction in $\mathrm{T}_{1}$. This extra relaxation enhancement by free $\mathrm{O}_{2}$ has been studied in arterial blood, plasma and CSF $(14,28,42)$ and found to depend linearly on $\mathrm{R}_{1}$ as described by: $\mathrm{R} 1=0.00027 \mathrm{xpO} 2(\mathrm{mmHg})$ +0.2263 in CSF at $1.5 \mathrm{~T}(42), \mathrm{R} 1=0.00041 \times \mathrm{xpO} 2(\mathrm{mmHg})+0.56$ in arterial blood at $3 \mathrm{~T}$ (28) and $\mathrm{R} 1=0.00020 \times \mathrm{xpO} 2(\mathrm{mmHg})+0.31$ in plasma at $7 \mathrm{~T}(14)$.. The slopes of these equations represent the $\mathrm{pO}_{2}$ dependence of $\mathrm{R}_{1}$. Therefore, a variation of arterial blood $\mathrm{pO}_{2}$ over the typical physiological range of $95+/-13 \mathrm{mmHg}$ (43) can induce $\mathrm{R}_{1}$ differences of $0.002-0.004 \mathrm{~s}^{-1}$, which are within the experimental error range. Most of our whole blood data were in this range, but some of the fully oxygenized lysed blood data used for calculating $\mathrm{r}_{1 \mathrm{dia}, \mathrm{Hb}}$ over this range were not. To correct for the $\mathrm{pO} 2$ effect, the $\mathrm{R}_{1}$ of these lysed blood data with $\mathrm{pO}_{2}$ outside the mentioned range were calibrated to the condition of $\mathrm{pO}_{2}=95 \mathrm{mmHg}$ using the equation $\mathrm{R}_{1, \text { cal }}=\mathrm{R}_{1, \exp }-0.00020\left(\mathrm{pO}_{2}-95\right)$. The $\mathrm{pO}_{2}$ of the fully lysed blood samples for calculating $\mathrm{r}_{1 \text { para,MetHb }}$ were not measured, because the samples with different MetHb concentrations for the same magnetic field were prepared by pouring $50 \mathrm{~mL}$ lysed blood from the same batch and $\sim 1 \mathrm{~mL}$ sodium nitrite into $50 \mathrm{~mL}$ tubes and tightly sealed. The experiments at the same magnetic field were finished at nearly the same time, so $\mathrm{pO}_{2}$ across different samples were nearly the same. Fortunately, the lack of this 


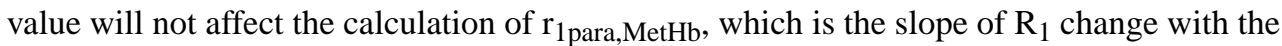
concentration of MetHb.

A blood analyzer (Radiometer, ABL700) was used to monitor hematocrit fraction (Hct), oxygen partial pressure $\left(\mathrm{pO}_{2}\right)$, oxygenation saturation $\left(\mathrm{sO}_{2}\right)$, total hemoglobin concentration $(\mathrm{ctHb})$ and methemoglobin fraction $\left(\mathrm{f}_{\mathrm{MetHb}}\right)$ immediately before and after every experiment. Note that Hct value reported by the blood analyzer is calculated based on total hemoglobin concentration in the blood (ctHb) according to an empirical relationship Hct $=0.00301 \times$ $\mathrm{ctHb}(\mathrm{g} / \mathrm{L})$ (reference manual of the ABL700 blood analyzer). This corresponds to a hemoglobin concentration in erythrocyte (mean corpuscular hemoglobin concentration, $\mathrm{MCHC}$ ) of $332 \mathrm{~g} / \mathrm{L}$ (44). The oxygen saturation $\left(\mathrm{sO}_{2}\right)$ is the ratio between oxygenated hemoglobin concentration and total hemoglobin concentration (the sum of oxygenated and deoxygenated hemoglobin concentration). The oxygenation fraction $(\mathrm{Y})$ is defined as $\mathrm{sO}_{2} / 100 \%$.

\section{MR Methods}

The MR experiments were conducted on 3T and 7T whole body scanners (Philips Medical Systems, Best, The Netherlands) as well as on 9.4T, 11.7T spectrometers (Bruker Biospin, Billerica, USA). A conventional inversion recovery sequence was used to measure $T_{1}$, with recovery time of $15 \mathrm{~s}$ after each acquisition to relax the system back to equilibrium and have a consistent initial magnetization. The total TR thus increases with the inversion time (TI), but the initial magnetization is always the same. TI-values used were $0.1 \mathrm{~s}, 0.4 \mathrm{~s}, 0.7 \mathrm{~s}, 1 \mathrm{~s}$, $1.4 \mathrm{~s}, 1.9 \mathrm{~s}, 2.5 \mathrm{~s}, 4 \mathrm{~s}, 6 \mathrm{~s}, 9 \mathrm{~s}$ for $3 \mathrm{~T}$ and $7 \mathrm{~T}$ scanners, and $0.1 \mathrm{~s}, 0.2 \mathrm{~s}, 0.4 \mathrm{~s}, 0.8 \mathrm{~s}, 1 \mathrm{~s}, 1.2 \mathrm{~s}, 1.5 \mathrm{~s}$, $1.8 \mathrm{~s}, 2.2 \mathrm{~s}, 2.5 \mathrm{~s}, 3 \mathrm{~s}, 4 \mathrm{~s}, 5 \mathrm{~s}, 8 \mathrm{~s}, 12 \mathrm{~s}, 15 \mathrm{~s}, 20 \mathrm{~s}$ for $9.4 \mathrm{~T}$ and $11.7 \mathrm{~T}$ spectrometers. The experiments performed at $3 \mathrm{~T}$ used a quadrature head coil and the following imaging parameters: FOV $=32 \times 32 \mathrm{~mm}^{2}$, matrix $=32 \times 32$, single-short EPI, $10 \mathrm{~ms}$ no-slice-selection hyperbolic secant inversion pulse. A single slice (10mm thick) in the center region of the tube was imaged. A small dephasing gradient $(0.6 \mathrm{mT} / \mathrm{m})$ was applied continuously during the inversion delay time to minimize possible radiation damping effects $(17,45,46)$. A similar protocol was applied on the 7T human scanner, as detailed in a previous paper (14). The experiments performed on spectrometers used quadrature volume coils with a $60 \mu \mathrm{s} 180^{\circ}$ inversion pulse and a small dephasing gradient $(0.10 \mathrm{G} / \mathrm{cm})$ during the inversion delay time.

\section{Blood $\mathrm{T}_{1}$ Model}

Here we build up the theory from basic principles to combine the individual components that are needed to describe the contributions of water in the erythrocyte (affected by the diamagnetic and paramagnetic relaxation of hemoglobin and the paramagnetic relaxation of methemoglobin) and water in plasma (affected by albumin and free $\mathrm{O}_{2}$ ). The hemoglobin relaxation is affected by the oxygenation fraction $\mathrm{Y}$ and the iron oxidative state $\left(\mathrm{Fe}^{2+}\right.$ versus $\mathrm{Fe}^{3+}$ ), while the relative contribution of the two compartments depends on the water fraction $\left(f_{\text {water }}\right)$ in each compartment, often approximated using the Hct but more accurately calculated from the hemoglobin and albumin concentrations for erythrocytes and plasma, respectively. The addition of the components depends on the exchange regime for the MRI measurement. A two-compartment "fast exchange" model (47) has been applied to describe blood $\mathrm{T}_{1}$ measured by inversion recovery experiments because the water exchange rate 
between plasma and cytoplasm is much faster than difference between the longitudinal relaxation rates between these two compartments $(14,48)$. The baseline equation for the resulting single-compartment rate then is:

$$
R_{1, \text { blood }}=f_{\text {ery }, \text { water }} \times R_{1, \text { ery }}+\left(1-f_{\text {ery }, \text { water }}\right) \times R_{1, \text { plasma }}
$$

with $\mathrm{f}_{\text {ery,water }}$ the water fraction in the erythrocyte, which can be derived to be $(14,49,50)$

$$
f_{\text {ery }, \text { water }}=\frac{0.70 \times H c t}{0.70 \times H c t+0.95 \times(1-H c t)}
$$

based on the fact that hemoglobin occupies about $30 \%$ of the volume (51) in the erythrocyte and water volume fraction in the plasma is about $95 \%(49,50)$ mainly due to the high concentration of albumin. $\mathrm{R}_{1 \text {,plasma }}$ is the longitudinal relaxation rate of water in plasma, and $R_{1, \text { ery }}$ is the water longitudinal relaxation rate of water in the erythrocyte.

Diamagnetic relaxation enhancement-In a protein solution like plasma (albumin solution) and cytoplasm in the erythrocyte (hemoglobin solution), the large protein will slow down the water tumbling and increase the water longitudinal relaxation rate. This diamagnetic effect is a short range effect limited to a thin "hydration shell" (52), where water tumbling is slow and the cross relaxation between water and protein is strong (53-55). Due to the fast exchange between water in this hydration shell and bulk water, the diamagnetic relaxation enhancement (relative to plasma) $\Delta R_{1, \mathrm{dia}}$ can be expressed as

$$
\Delta R_{1 \text { dia }}=\Delta R_{1 \text { dia,shell }} \frac{V_{\text {shell }}}{V_{\text {bulk }}}
$$

$\Delta \mathrm{R}_{1 \text { dia,shell }}$ is the relaxation enhancement (relative to saline solution) of water in the hydration shell. $\mathrm{V}_{\text {shell }}$ and $\mathrm{V}_{\text {bulk }}$ are the water volumes in the hydration shell and in protein solution. Because the hydration shell is thin and its volume proportional to the protein volume, $\Delta \mathrm{R}_{1 \text {,dia }}$ can be rewritten as

$$
\begin{gathered}
\Delta R_{1 \text { dia }}=\Delta R_{1 \text { dia, shell }} \frac{a V_{\text {Alb }}}{V_{\text {bulk }}}=\Delta R_{1 \text { dia, shell }} \frac{a \times m_{\text {protein }} / \rho_{\text {protein }}}{m_{\text {water }} / \rho_{\text {water }}} \\
=\left[\Delta R_{1 \text { dia }, \text { shell }} \times a \times \frac{\rho_{\text {water }}}{\rho_{\text {protein }}} \times M_{\text {protein }}\right] \frac{n_{\text {protein }}}{m_{\text {water }}}
\end{gathered}
$$

where $\mathrm{a}$ is the volume ratio between the hydration shell and protein molecule, and $\mathrm{m}_{\text {protein }}$, $\mathrm{V}_{\text {protein, }} \rho_{\text {protein }}, \mathrm{n}_{\text {protein }}, \mathrm{M}_{\text {protein }}$ are the mass, volume, density, number of moles and molecular weight of the protein, $\mathrm{m}_{\text {water }}$ is the water mass in the protein solution. Therefore, the diamagnetic relaxation enhancement of protein can be expressed as 


$$
\Delta R_{1 \text { dia }}=r_{1 \text { dia }} \times b_{\text {protein }}
$$

where $r_{1 \text { dia }}=\Delta R_{1 \text { dia,shell }} \times a \times \frac{\rho_{\text {water }}}{\rho_{\text {protein }}} \times M_{\text {protein }}$ and $b_{\text {protein }}=n_{\text {protein } /} m_{\text {protein }}$ are the diamagnetic relaxivity and molality of the protein, respectively. The molality can be related to the mass concentration of protein $\left(c_{\text {protein }} \mathrm{g} / \mathrm{L}\right)$ via:

$$
b_{\text {protein }}=\frac{n_{\text {protein }}}{m_{\text {water }}}=\frac{m_{\text {protein }} / M_{\text {protein }}}{m_{\text {water }}}=\frac{m_{\text {protein }} / V}{\left(m-m_{\text {protein }}\right) / V} \times \frac{1}{M_{\text {protein }}}=\frac{c_{\text {protein }}}{\rho-c_{\text {protein }}} \times \frac{1}{M_{\text {protein }}}
$$

with the solution volume $\mathrm{V}$, the solution mass $\mathrm{m}$ and the solution density $\rho$. The protein in plasma is mainly albumin (56), therefore the longitudinal relaxation of water in plasma can be written as

$$
R_{1 \text { plasma }}=R_{1 \text { saline }}+r_{1 \text { dia }, A l b} \times b_{A l b}
$$

in which $\mathrm{R}_{1 \text { saline }}$ is the water longitudinal relaxation rate in saline solution and $\mathrm{r}_{1 \mathrm{dia} \text {,Alb }}$ is the diamagnetic relaxivity of water due to albumin. According to Eq. [6], the molality concentration of albumin $\mathrm{b}_{\mathrm{Alb}}$ can be calculated via:

$$
b_{A l b}=\frac{c_{A l b}(g / L)}{\left[\left(0.501 \times{ }_{A l b}+1000\right)-c_{A l b}\right](g / L)} \times \frac{1}{66.5 \mathrm{~kg} / \mathrm{mol}}
$$

The coefficient of 0.501 in the plasma density $\rho_{\text {plasma }}$ was obtained from linear extrapolation between the density with the protein $(1025 \mathrm{~g} / \mathrm{L})(57)$ and the water density (i.e. zero protein concentration). This can be done because the protein solution density has a linear dependence on the protein concentration (58) and the albumin concentration is known: $\mathrm{c}_{\mathrm{Alb}}=0.75 \mathrm{mM} \times 66.5 \mathrm{~kg} / \mathrm{mol}=49.9 \mathrm{~g} / \mathrm{L}(14)$.

The diamagnetic relaxation enhancement (relative to saline water) in the erythrocyte is mainly attributed to the hemoglobin, and can be expressed as

$$
\Delta R_{1 d i a, H b}=r_{1 d i a, H b} \times b_{H b}
$$

$\mathrm{r}_{1 \mathrm{dia}, \mathrm{Hb}}$ is the diamagnetic relaxivity of hemoglobin. The molality $\mathrm{b}_{\mathrm{Hb}}$ can be related to the concentration of hemoglobin $\left(\mathrm{c}_{\mathrm{Hb}}\right)$ via

$$
b_{H b}=\frac{c_{H b}(g / L)}{\left[\left(0.377 \times c_{H b}+1000\right)-c_{H b}\right](g / L)} \times \frac{1}{64.5 \mathrm{~kg} / \mathrm{mol}}
$$


The factor 0.377 in the cytoplasm density $\rho_{\text {cytoplasm }}$ was determined from linear extrapolation between solution and pure water, similar to albumin above but now using the erythrocyte cytoplasm density of $1125 \mathrm{~g} / \mathrm{L}(44,59)$ and the erythrocyte hemoglobin concentration of $332 \mathrm{~g} / \mathrm{L}$. Notice that the overall structures of oxyhemoglobin, deoxyhemoglobin and methemoglobin are comparable under the same physiological conditions (temperature, $\mathrm{pH}$, etc), causing these three types of hemoglobin to share the same diamagnetic relaxivity $\mathrm{r}_{1 \mathrm{dia}, \mathrm{Hb}}$.

Paramagnetic relaxation enhancement-Similar to the diamagnetic effect, the paramagnetic relaxation enhancements of methemoglobin and deoxyhemoglobin, which also depend linearly on their concentration, can be expressed as

$$
\Delta R_{1 \text { para }, \text { MetHb }}=r_{1 \text { para }, \text { MetHb }} \times b_{\text {MetHb }} \quad[11 \mathrm{a}]
$$

$$
\Delta R_{1 \text { para, deoxyHb }}=r_{1 \text { para, deoxyHb }} \times b_{\text {deoxyHb }}
$$

where $r_{1 \text { para,MetHb }}$ and $r_{1 \text { para,deoxyHb }}$ are the paramagnetic relaxivities of methemoglobin and deoxyhemoglobin respectively. $b_{\mathrm{MetHb}}$ and $\mathrm{b}_{\mathrm{deoxyHb}}$ are the molalities of methemoglobin and deoxyhemoglobin in the erythrocyte, that can be related to the total molality of hemoglobin $\mathrm{b}_{\mathrm{Hb}}$ through

$$
\begin{gathered}
b_{M e t H b}=b_{H b} \times f_{M e t H b} \quad[12 \mathrm{a}] \\
b_{\text {deoxy } H b}=b_{H b} \times\left[1-\left(1-f_{M e t H b}\right) \times Y-f_{M e t H b}\right]=b_{H b} \times\left(1-f_{M e t H b}\right) \times(1-Y)
\end{gathered}
$$

Under physiological conditions, the hemoglobin protein is a tetramer (60). While multiple possible tetramers can exist (e.g. binding one, two, three or four $\mathrm{O}_{2}$ ), it can be calculated from the binding constants that hemoglobin exists predominantly as a mixture of the fully oxygenated state (all four $\mathrm{O}_{2}$ binding sites occupied) and the fully deoxygenated state in the normal oxygenation range (61-64). Thus, thanks to this well-known cooperative binding process, one relaxivity parameter $\left(\mathrm{r}_{1 \text { para,deoxyHb }}\right)$ is sufficient to approximate the paramagnetic effect of deoxy-hemoglobin. Therefore the water $\mathrm{R}_{1}$ in erythrocyte can be expressed as

$R_{1, e r y}=b_{H b} \times\left[r_{1 d i a, H b}+r_{1 \text { para }, \text { deoxy } H b} \times\left(1-f_{\text {MetHb }}\right) \times(1-Y)+r_{1 \text { para }, \text { MetHb }} \times f_{\text {MetHb }}\right]+R_{1 \text { saline }}$

and the blood water $\mathrm{R}_{1}$ can be written as

Magn Reson Med. Author manuscript; available in PMC 2017 July 01. 


$$
\begin{gathered}
R_{1, \text { blood }}= \\
f_{\text {ery }, \text { water }} \times\left\{b_{H b} \times\left[r_{1 \text { dia }, H b}+r_{1 \text { para, deoxy } H b} \times\left(1-f_{\text {MetHb }}\right) \times(1-Y)+r_{1 p a r a, \text { MetHb }} \times\right.\right. \\
\left.\left.f_{\text {MetHb }}\right]+R_{1 \text { saline }}\right\}+\left(1-f_{\text {ery }, \text { water }}\right) \times\left[R_{1 \text { saline }}+r_{1 \text { dia }, \text { Alb }} \times b_{\text {Alb }}\right]
\end{gathered}
$$

\section{Data Fitting}

Averages of the magnitude intensities at the center of the slice profiles (scanners) and the integrals of the water peaks (spectrometers) were fitted as a function of inversion time (TI) using the following model valid under conditions of $\mathrm{TR}>5 \mathrm{~T}_{1}$ :

$$
S(T I)=\left|S_{0}\left(1-C e^{-T I / T_{1}}\right)\right|
$$

The equilibrium signal $\mathrm{S}_{0}$, the inversion efficiency $\mathrm{C}$ and blood ${ }^{1} \mathrm{H}_{2} \mathrm{O} \mathrm{R}_{1}\left(1 / \mathrm{T}_{1}\right)$ were fitted using a nonlinear-least squares algorithm. The errors of fitted $\mathrm{R}_{1}$ were calculated as $95 \%$ confidence interval in the fitting.

In whole blood, multiple $\mathrm{T}_{1}$ data at $3 \mathrm{~T}, 7 \mathrm{~T}, 9.4 \mathrm{~T}, 11.7 \mathrm{~T}$, at various $\mathrm{Y}(0.48-1.00)$, Hct $(0.31$ - 0.75) and $\mathrm{f}_{\mathrm{MetHb}}(0.016-0.028)$ were fitted using Eq. [14]. The blood sample Hct, $\mathrm{Y}$ and $\mathrm{f}_{\mathrm{MetHb}}$ were read directly from the blood analyzer. Albumin's concentration was set as 0.75 $\mathrm{mM}$ (14) or $0.77 \mathrm{mmol} / \mathrm{kg}$ (Eq. [6]). The hemoglobin molalities $\mathrm{b}_{\mathrm{Hb}}$ were calculated to be $6.49 \mathrm{mmol} / \mathrm{kg}$ (Eq. [10]) assuming that the hemoglobin concentration $\left(\mathrm{c}_{\mathrm{Hb}}\right)$ in erythrocytes was the normal MCHC of $332 \mathrm{~g} / \mathrm{L}(34,35)$. The water fractions in erythrocyte $\mathrm{f}_{\text {ery,water were }}$ calculated from Hct according to Eq. [2]. The $\mathrm{r}_{1 \mathrm{dia}, \mathrm{Alb}}, \mathrm{r}_{1 \mathrm{dia}, \mathrm{Hb}}$ and $\mathrm{r}_{1 \text { para,MetHb }}$ obtained from the linear fits of plasma and lysed blood samples were directly used in the fitting. A Matlab (Mathworks, Natick, MA) function fmincon was used to minimize the relative error | $\mathrm{R}_{1, \text { exp }}-\mathrm{R}_{1, \text { fitted }} / \mathrm{R}_{1, \text { exp }}$.

\section{Results}

The paramagnetic effect of methemoglobin was studied by measuring $R_{1}$ of fully oxygenated lysed blood samples with different methemoglobin fractions and the same total hemoglobin concentration (Figure 1). Because the diamagnetic effects from normal hemoglobin and methemoglobin are the same, $\mathrm{r}_{1 \mathrm{para}, \mathrm{MetHb}}$ could be directly derived from the slope as listed in Table 1.

Combining water $\mathrm{R}_{1}$ data in plasma and saline solution at $37{ }^{\circ} \mathrm{C}$ (Table 2), the diamagnetic relaxivity of albumin at $\mathrm{c}_{\mathrm{Alb}}=0.75 \mathrm{mM}(14)$ was calculated as

$$
r_{1 \text { dia }, A l b}=\frac{R_{1 \text { plasma }}-R_{1 \text { saline }}}{{ }^{b} \text { Alb }}
$$

and listed in Table 1. 
The diamagnetic effect of hemoglobin $\mathrm{r}_{1 \mathrm{dia}, \mathrm{Hb}}$ was studied by measuring $\mathrm{R}_{1}$ of fully oxygenated lysed blood samples with different hemoglobin concentrations (Figure 2).

Because the lysed blood samples with targeted hemoglobin concentrations were prepared by mixing plasma, albumin concentrations in different samples were different. Moreover, the methemoglobin concentrations in different samples were different. Therefore, the measured $\mathrm{R}_{1}$ should be corrected by removing contributions of albumin's diamagnetic relaxation and methemoglobin's paramagnetic relaxation following Eq. [17].

$$
\Delta R_{1}=R_{1}-r_{1 \text { para }, M e t H b} \times f_{M e t H b} \times b_{H b}-r_{1 d i a, A l b} \times b_{A l b}
$$

Fig. $2 \mathrm{~b}$ shows the linear fitting of this corrected lysed blood $\Delta \mathrm{R}_{1}$ (Table 3 ) as a function of hemoglobin concentration. The $\mathrm{r}_{1 \mathrm{dia}, \mathrm{Hb}}$ was derived from the slope (Table 4).

To verify our model for whole blood, multiple whole blood $\mathrm{R}_{1}$ data (Table 4) at $3 \mathrm{~T}, 7 \mathrm{~T}, 9.4 \mathrm{~T}$, $11.7 \mathrm{~T}$, at various $\mathrm{Y}(0.48-1.00)$, Hct $(0.31-0.75)$ and $\mathrm{f}_{\mathrm{MetHb}}(0.016-0.028)$ were fitted using Eq. [14]. Figure 3 shows a summary of the fitting accuracy, indicating that our model fitted the experimental data well, with average relative error $\left(\mathrm{R}_{1}-\mathrm{R}_{1, \mathrm{fit}}\right) / \mathrm{R}_{1}$ of $1.4 \%$. The fitted parameters $\mathrm{r}_{1 \text { para,deoxyHb }}$ and $\mathrm{R}_{1 \text { saline }}$ are listed in Table 1 , and the fitted $\mathrm{R}_{1 \text { saline }}$ agreed with the $\mathrm{R}_{1 \text { saline }}$ measured separately in experiments (Table 2 ).

Fig. 4 shows the magnetic field dependence of the diamagnetic relaxivity of hemoglobin (Fig. 4a), diamagnetic relaxivity of albumin (Fig. 4b), paramagnetic relaxivity of deoxyhemoglobin (Fig. 4c) and paramagnetic relaxivity of methemoglobin (Fig. 4d), and the water $\mathrm{R}_{1}$ of saline solution (Fig. 4e). The diamagnetic relaxivities of albumin and hemoglobin were fitted (Figs 4a,b) using the following empirical equation proposed by Lindstrom and Koenig (16).

$$
r_{1, d i a}=P_{1} \times \frac{P_{2}}{1+\left(\gamma_{H} B_{0} \times P_{2}\right)^{P_{3}}}+P_{4}
$$

with the ${ }^{1} \mathrm{H}$ gyromagnetic ratio $\gamma_{\mathrm{H}}$ and empirical constants $\mathrm{P}_{1}=9.45 \times 10^{9} \mathrm{~s}^{-2} \times \mathrm{kg} / \mathrm{mol}, \mathrm{P}_{2}=$ $2.88 \times 10^{-4} \mathrm{~s}, \mathrm{P}_{3}=0.822$ and $\mathrm{P}_{4}=64.9(\mathrm{~s} \times \mathrm{mol} / \mathrm{kg})^{-1}$ for $\mathrm{r}_{1 \mathrm{dia}, \mathrm{Alb}}$ and $\mathrm{P}_{1}=4.22 \times 10^{15}$ $\left(\mathrm{s}^{-2} \times \mathrm{kg} / \mathrm{mol}\right), \mathrm{P}_{2}=4.55 \times 10^{-4} \mathrm{~s}, \mathrm{P}_{3}=1.97$ and $\mathrm{P}_{4}=42.9(\mathrm{~s} \times \mathrm{mol} / \mathrm{kg}){ }^{-1}$ for $\mathrm{r}_{1 \mathrm{dia}, \mathrm{Hb}}$. The

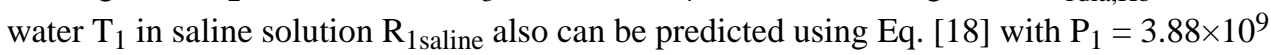
$\mathrm{s}^{-2}, \mathrm{P}_{2}=6.68 \times 10^{-11} \mathrm{~s}, \mathrm{P}_{3}=1.11$ and $\mathrm{P}_{4}=2.41 \times 10^{-3} \mathrm{~s}^{-1}$. The paramagnetic relaxivities of deoxyhemoglobin and methemoglobin were fitted (Figs $4 \mathrm{c}, \mathrm{d}$ ) using the outer sphere model of Freed $(65,66)$ which described the water molecules diffusing around the paramagnetic complex:

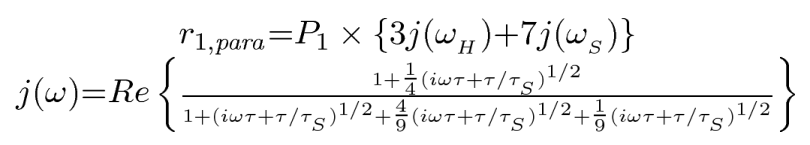

Magn Reson Med. Author manuscript; available in PMC 2017 July 01. 
with the proton and electron Larmor frequencies $\omega_{\mathrm{H}}$ and $\omega_{\mathrm{S}}$, and empirical constants $\mathrm{P}_{1}=$ $6.40 \times 10^{6}(\mathrm{~s} \times \mathrm{mol} / \mathrm{kg})^{-1}, \tau=9.72 \times 10^{-6} \mathrm{~s}, \tau_{\mathrm{S}}=3.07 \times 10^{-10} \mathrm{~s}$ for $\mathrm{r}_{1 \text { para,MetHb}}$, and $\mathrm{P}_{1}=$

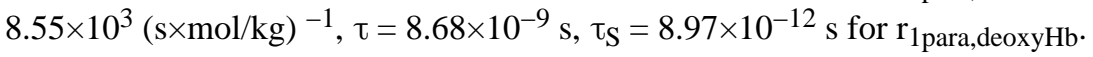

\section{Discussion}

Lysed and whole blood experimental $\mathrm{R}_{1}$ data were used to validate a simple longitudinal relaxation model for blood water and to evaluate the paramagnetic and diamagnetic effects of albumin, hemoglobin and methemoglobin at multiple fields. For the diamagnetic relaxivities of hemoglobin, previous studies $(8,10,14,17,20,21,23,26-28)$ have quantitatively described the diamagnetic relaxation enhancement of hemoglobin as Hct dependence using the empirical equation $\mathrm{R}_{1}=\mathrm{A} \times \mathrm{Hct}+\mathrm{B}$. In our model, this $\mathrm{Hct}$ dependent coefficient $\mathrm{A}$ can be approximated by the product of the diamagnetic relaxivity $\mathrm{r}_{1 \mathrm{dia}, \mathrm{Hb}}$ and the hemoglobin concentration in the erythrocyte $\left(\mathrm{b}_{\mathrm{Hb}}=6.49 \mathrm{mmol} / \mathrm{kg}\right.$ ), which is $0.41 \mathrm{~s}^{-1}$ at $3 \mathrm{~T}$ and $0.29 \mathrm{~s}^{-1}$ at 7T. This is comparable to the reported A value as $\sim 0.5 \mathrm{~s}^{-1}$ at $3 \mathrm{~T}(17,20)$ and $0.34 \mathrm{~s}^{-1}$ at $7 \mathrm{~T}$ (19) in the previous human or bovine blood studies. As shown in Fig 4, the diamagnetic longitudinal relaxivities of albumin and hemoglobin decrease as magnetic field increases, which follows the trend observed by Lindstrom and Koenig (16) in the CO bound hemoglobin solution. Therefore, the equation from Lindstrom and Koenig (16) (Eq. [18]) was used to fit $r_{1 \text { dia,Alb }}$ and $r_{1 \text { dia,Hb }}$ in the Fig 4 . Note that we have only limited number of field data for this multiple parameter fit, but can be used to numerically extrapolate and estimate diamagnetic relaxivity values at unknown magnetic fields around our measured magnetic field range.

Our paramagnetic relaxivities of deoxyhemoglobin $\mathrm{r}_{1 \text { para,deoxyHb }}$ (per hemoglobin complex) at $3 \mathrm{~T}\left(65.6\left(\mathrm{~mol} / \mathrm{kg} \times s^{-1}\right)\right.$ and $7 \mathrm{~T}\left(56.2\left(\mathrm{~mol} / \mathrm{kg} \times s^{-1}\right)\right.$ agree reasonably with $\mathrm{r}_{1 \text { para,deoxyHb }}$ reported by Blockley et al. (10) as $14.6 \times 4(\mathrm{~mol} / \mathrm{L} \times \mathrm{s})^{-1}$ per hemoglobin at $3 \mathrm{~T}$ and $10.6 \times 4$ $(\mathrm{mol} / \mathrm{L} \times \mathrm{s})^{-1}$ per hemoglobin at $7 \mathrm{~T}$. Our paramagnetic relaxivities of methemoglobin $\mathrm{r}_{1 \text { para,MetHb }}$ (per hemoglobin complex) are also comparable to the $\mathrm{r}_{1 \text { para,MetHb }}$ of $175 \times 4$ $(\mathrm{M} \times \mathrm{s})^{-1}$ per hemoglobin measured at $220 \mathrm{MHz}$ (67). At the same time, the paramagnetic relaxivity of methemoglobin $\mathrm{r}_{1 \text { para,MetHb }}$ decreases with increasing magnetic field following the NMR relaxation dispersion curve measured by Koenig et al. (68), while the paramagnetic relaxivities of deoxyhemoglobin $r_{1 \text { para,deoxyHb have weak magnetic field }}$ dependence which was also observed by Blockley et al. (10). Although initial studies about the paramagnetic relaxation in methemoglobin attributed the relaxation enhancement to the "inner sphere" $(67,69)$ mechanism, i.e. only water ligated with heme relaxes fast, and then exchange with bulk water. However, an extensive investigation of proton relaxation dependence on temperature (70) had shown that the exchange rate between ligated water and bulk water was not fast enough to induce the fast relaxation, and Koenig et al. (36) measured the relaxation dispersion curve at multiple magnetic fields and proved the "outer sphere" mechanism, i.e. the fluctuation of the dipolar coupling between water and paramagnetic protein due to water diffusion, dominated the paramagnetic relaxation. Therefore, Freed's diffusion model $(65,66)$ which described water molecules diffusing around the paramagnetic complex was used to fit the field dependence of the paramagnetic relaxivities of methemoglobin and deoxyhemoglobin in Fig 4. Similar to the fitting of diamagnetic 
relaxivity dependence on the magnetic field, the fit of Eq. [19] should be considered as a numerical extrapolation due to the limited number of experimental data.

The good fitting of our model in terms of the difference between the experimental and predicted $\mathrm{T}_{1}$ values over a large number of blood data (Fig. 3) supports our model and thus should allow the fitted relaxivities at multiple fields $(3.0 \mathrm{~T}, 7.0 \mathrm{~T}, 9.4 \mathrm{~T}$ and $11.7 \mathrm{~T})$ to be used to calculate the blood $\mathrm{T}_{1}$ for quantitative MRI experiments. Table 5 compares the blood $\mathrm{T}_{1}$ calculated from our model and the human blood $\mathrm{T}_{1}$ measured by other groups. They agree well except for a venous blood $\mathrm{T}_{1}$ measured at $7 \mathrm{~T}$ by Rooney et al. (29). Therefore, the blood $\mathrm{T}_{1}$ calculated from our model (Table 6) can be a reference for studies on 9.4T and 11.7T animal scanners as well as on ultra high human field scanners that are now becoming available. In addition to adult blood, the results in Table 5 show that our model is also able to predict blood $\mathrm{T}_{1}$ in neonates. In neonate blood, the fetal erythrocyte's cell volume (MCV) is $20 \%$ larger than adult erythrocyte (71), and the most of hemoglobin is hemoglobin F, which replaces two beta subunits with two gamma subunits, but has similar overall structure as the adult hemoglobin. This shows the versatility of our model to predict abnormal blood $\mathrm{T}_{1}$.

Besides predicting blood $\mathrm{T}_{1}$ values at $3 \mathrm{~T}, 7 \mathrm{~T}, 9.4 \mathrm{~T}, 11.7 \mathrm{~T}$, the blood $\mathrm{T}_{1}$ at other fields can also be predicted from the curves in Fig 4. For example, using Eq. [18], Eq. [19] and our fitted parameters, we can extrapolate the relaxivities at $4.7 \mathrm{~T}$ as $\mathrm{r}_{1 \mathrm{dia}, \mathrm{Hb}}$ of $51.1 \mathrm{(mol} /$ $\mathrm{kg} \times \mathrm{s})^{-1}, \mathrm{r}_{1 \mathrm{dia}, \mathrm{Alb}}$ of $138(\mathrm{~mol} / \mathrm{kg} \times \mathrm{s})^{-1}, \mathrm{r}_{1 \text { para,deoxyHb }}$ of $61.7(\mathrm{~mol} / \mathrm{kg} \times \mathrm{s})^{-1}, \mathrm{r}_{1 \text { para,MetHb }}$ of $1.19 \times 10^{3}(\mathrm{~mol} / \mathrm{kg} \times \mathrm{s})^{-1}$ and $\mathrm{R}_{1 \text { saline }}$ of $0.246 \mathrm{~s}^{-1}$. Meyer et al. (27) measured at 4.7T the oxygenation dependence of bovine blood (Hct=0.4) as $\mathrm{R}_{1}=\mathrm{A} \times(1-\mathrm{Y})+\mathrm{B}$, where $\mathrm{A}=0.12+$ / $-0.03 \mathrm{~s}^{-1}$ was defined as the paramagnetic coefficient of deoxyhemoglobin. According to Eq. [14], this paramagnetic coefficient $A$ can be expressed as $f_{\text {ery,water }} \times b_{H b} \times r_{1 \text { para,deoxyHb, }}$, which can be calculated as $0.13 \mathrm{~s}^{-1}$ based on our fitted parameters $\mathrm{r}_{1 \text { para,deoxyHb }}(61.7$ (mol/ $\mathrm{kg} \times \mathrm{s})^{-1}$ ) and agrees well with the result from Meyer et al. (27). At the same time, Dobre et al. (11) measured bovine blood $\mathrm{T}_{1}$ as $1833+/-49 \mathrm{~ms}$ at $\mathrm{Hct}=0.43+/-0.03$ and $\mathrm{Y}=0.81+/$ -0.13 . Assuming a $\mathrm{f}_{\mathrm{MetHb}}=2 \%$ for the regular bovine blood, we calculated blood $\mathrm{T}_{1}$ as 2004 ms under the same conditions based on our fitted relaxivities, which is similar to the result from Dobre et al. (11). Extrapolating to relaxation times at 1.5T is less accurate due to the nonlinear steeper field dependence of the diamagnetic albumin and diamagnetic and paramagnetic hemoglobin relaxivities (Figs. 4a-c). When extrapolating relaxivities at $1.5 \mathrm{~T}$, we found $\mathrm{r}_{1 \mathrm{dia}, \mathrm{Hb}}=121(\mathrm{~mol} / \mathrm{kg} \times \mathrm{s})^{-1}, \mathrm{r}_{1 \text { dia,Alb }}=253(\mathrm{~mol} / \mathrm{kg} \times \mathrm{s})^{-1}, \mathrm{r}_{1 \text { para, ,deoxyHb }}=80.3$ $(\mathrm{mol} / \mathrm{kg} \times \mathrm{s})^{-1}, \mathrm{r}_{1 \text { para,MetHb }}=1.34 \times 10^{3}(\mathrm{~mol} / \mathrm{kg} \times \mathrm{s})^{-1}$ and $\mathrm{R}_{1 \text { saline }}=0.257 \mathrm{~s}^{-1}$. Using these numbers to estimate the arterial blood $\mathrm{T}_{1}$ at $\mathrm{Hct}=0.36-0.53$ at $1.5 \mathrm{~T}$, we found it to be $1367-1585 \mathrm{~ms}$ for a methemoglobin fraction of 0.004 . This is comparable with a previous in vivo human study (1499+/-74ms, (20)), in vitro human blood study (1435 ms (9), measured at $\left.23^{\circ} \mathrm{C}\right)$ and in vitro bovine blood study $(1400 \mathrm{~ms},(72))$. The venous blood $\mathrm{T}_{1}$ measured in sagittal sinus (25) is also comparable to our prediction (Table 2).

The blood $\mathrm{T}_{1}$ predicted from our model can also be used to evaluate the MRI experiments related to blood $\mathrm{T}_{1}$ such as the VASO experiment to determine the relative cerebral blood volume (CBV) change during activation (3) and the ASL experiment to measure cerebral blood flow (CBF) (77). The quantification in both experiments depends on the accuracy of the blood $\mathrm{T}_{1}$ value used because the VASO experiment uses blood $\mathrm{T}_{1}$ to calculate an 
inversion time (TI) to null the blood signal while blood $\mathrm{T}_{1}$ is an important parameter in ASL experiment to calculate the label decay. When performing these experiments, the blood $\mathrm{T}_{1}$ is generally considered to be a constant at certain magnetic field, but as we discussed, even in a healthy human, the blood $\mathrm{T}_{1}$ could vary in a range due to different $\mathrm{Hct}, \mathrm{Y}$ (venous blood) and $\mathrm{f}_{\mathrm{MetHb}}$. For example, in healthy people, Hct has a $\sim 10 \%$ variation $(71), \mathrm{f}_{\mathrm{MetHb}}$ has a $\sim 1 \%$ variation (73) while $\mathrm{Y}$ in venous blood has a range of $0.55-0.75(74,75)$. The blood $\mathrm{T}_{1}$ could change $100-150 \mathrm{~ms}$ at $3 \mathrm{~T}$ for these blood parameters' variation. Using the typical experiment conditions $(76,77)$, the CBV change during the activation could have a $1 \%-2 \%$ difference based on the equations in (76) while the CBF could have $20 \%$ difference for PCASL and $\sim 10 \%$ difference for QUIPSS II PASL based on the simple model in ASL "white paper" (77).

There are several assumptions in our model. The key assumption is that a single $\mathrm{R}_{1}$ dominates the inversion-recovery process of the blood despite the erythrocyte and plasma compartments having different $\mathrm{R}_{1}$ and that this single blood $\mathrm{R}_{1}$ can be simply expressed as the weighted sum of $R_{1}$ in plasma and erythrocyte (Eq. 1). According to chemical exchange theory (48), this assumption is valid when

$$
k_{\text {exch }} \gg\left|R_{1, \text { ery }}-R_{1, \text { plasma }}\right|
$$

in which $\mathrm{k}_{\mathrm{exch}}$ is the water exchange rate between plasma and erythrocyte. Using a lifetime of about $8 \mathrm{~ms}$ for water inside the erythrocyte (78), the exchange life time $\left(1 / \tau_{\text {exch }}=1 / \tau_{\text {ery }}\right.$ $\left.+1 / \tau_{\text {plasma }}\right)$ for this system would be $6.8 \mathrm{~ms}$ for hematocrit fraction $(\mathrm{Hct})=0.3$ and $2.5 \mathrm{~ms}$ for $\mathrm{Hct}=0.75$, corresponding to $k_{\text {exch }}\left(=1 / \tau_{\text {exch }}\right)$ values of 147 and $400 \mathrm{~Hz}$, respectively. This exchange rate is much faster than the $\mathrm{R}_{1}$ difference in erythrocyte and in plasma as measured in this study and many other studies. Note that this fast-exchange condition for $\mathrm{R}_{1}$ is different from the exchange-narrowing condition for $\mathrm{R}_{2}$ which requires water exchange rate between plasma and erythrocyte to be much faster than the water chemical shift difference in plasma and in erythrocyte. Even if the peaks for water in plasma and in erythrocyte are separated, they still share the same averaged longitudinal relaxation time as shown in Eq. 1. (48).

Another assumption in our model is that all hemoglobins are homogenous. This assumption is valid for the normal adult blood. But for sickle cell disease, the hemoglobin is mutated as $\mathrm{HbS}$ and forms fibers in its deoxy-state $(79,80)$. This different hemoglobin, especially the fibers formed by polymerization could change the water-protein interaction and thus the blood $\mathrm{T}_{1}$. According to a previous in vivo study, the blood $\mathrm{T}_{1}$ of patients with sickle cell disease is comparable to normal volunteers and thus the values found with our model (Table 5 ), but caution needs to be taken when using our model for sickle cell disease until more measurements of blood R1 under this condition confirm the above result.

\section{Conclusion}

We derived a comprehensive model for the effects of hemoglobin concentration, hematocrit fraction, oxygenation fraction, methemoglobin fraction and albumin concentration on the 
water ${ }^{1} \mathrm{H} \mathrm{T}_{1}$ in blood, and confirmed the equations experimentally in whole blood samples at 3T, 7T, 9.4T and 11.7T. The fitted parameters presented here provide a good calibration for calculating human blood $\mathrm{T}_{1}$, as demonstrated by excellent agreement with human blood $\mathrm{T}_{1 \text { values }}$ measured in vivo by other groups. Our model should be useful to predict blood $\mathrm{T}_{1}$ for arbitrary hemoglobin concentration, hematocrit fraction, oxygenation, methemoglobin fraction and albumin concentration at multiple fields.

\section{Acknowledgments}

Grant support: NIH: P41 EB015909, NIH: K25 HL121192

We are grateful to Drs. James Pekar and Paul Bottomley for helpful discussions. Grant support was provided by the National Institute of Health (NIH) (P41EB015909 and K25 HL121192).

\section{References}

1. Detre, Ja; Leigh, JS.; Williams, DS.; Koretsky, AP. Perfusion imaging. Magn Reson Med. 1992; 23:37-45. [PubMed: 1734182]

2. Edelman RR, Chien D, Kim D. Fast selective black blood MR imaging. Radiology. 1991; 181:655660. [PubMed: 1947077]

3. Lu H, Golay X, Pekar JJ, Van Zijl PCM. Functional magnetic resonance imaging based on changes in vascular space occupancy. Magn Reson Med. 2003; 50:263-274. [PubMed: 12876702]

4. Bradley WG. MR appearance of hemorrhage in the brain. Radiology. 1993; 189:15-26. [PubMed: 8372185]

5. Cohen M, McGuire W, Cory D, Smith J. MR appearance of blood and blood products - an in vitro study. Am J Roentgenol. 1986; 146:1293-1297. [PubMed: 3486571]

6. Bodansky O. Methemoglobinemia and methemoglobin-producing compounds. Pharmacol Rev. 1951; 3:144-196. [PubMed: 14843826]

7. Prchal JT, Gregg XT. Red cell enzymes. Hematology Am Soc Hematol Educ Program. 2005:19-23. [PubMed: 16304354]

8. Atalay MK, Reeder SB, Zerhouni EA, Forder JR. Blood oxygenation dependence of T1 and T2 in the isolated, perfused rabbit heart at 4.7T. Magn Reson Med. 1995; 34:623-627. [PubMed: 8524032]

9. Barth M, Moser E. Proton NMR relaxation times of human blood samples at $1.5 \mathrm{~T}$ and implications for functional MRI. Cell Mol Biol. 1997; 43:783-791. [PubMed: 9298600]

10. Blockley NP, Jiang L, Gardener AG, Ludman CN, Francis ST, Gowland PA. Field strength dependence of R1 and R2* relaxivities of human whole blood to ProHance, Vasovist, and deoxyhemoglobin. Magn Reson Med. 2008; 60:1313-1320. [PubMed: 19030165]

11. Dobre MC, Ugurbil K, Marjanska M. Determination of blood longitudinal relaxation time (T1) at high magnetic field strengths. Magn Reson Imaging. 2007; 25:733-735. [PubMed: 17540286]

12. Bryant RG, Marill K, Blackmore C, Francis C. Magnetic relaxation in blood and blood clots. Magn Reson Med. 1990; 13:133-144. [PubMed: 2319929]

13. Gomori J, Grossman R, Yuip C, Asakura T. NMR relaxation times of blood: dependence on field strength, oxidation state, and cell integrity. J Comput Assist Tomogr. 1987; 11:684-690. [PubMed: 3597895]

14. Grgac K, van Zijl PCM, Qin Q. Hematocrit and oxygenation dependence of blood (1)H2O T1 at 7 tesla. Magn Reson Med. 2013; 70:1153-1159. [PubMed: 23169066]

15. Lin AL, Qin Q, Zhao X, Duong TQ. Blood longitudinal (T1) and transverse (T2) relaxation time constants at 11.7 Tesla. Magn Reson Mater Phys Biol Med. 2012; 25:245-249.

16. Lindstrom TR, Koenig SH. Magnetic-field-dependent water proton spin-lattice relaxation rates of hemoglobin solutions and whole blood. J Magn Reson. 1974; 15:344-353.

17. Lu H, Clingman C, Golay X, van Zijl PCM. Determining the longitudinal relaxation time (T1) of blood at 3.0 Tesla. Magn Reson Med. 2004; 52:679-82. [PubMed: 15334591] 
18. Qin Q, Strouse JJ, van Zijl PCM. Fast measurement of blood T1 in the human jugular vein at 3 Tesla. Magn Reson Med. 2011; 65:1297-304. [PubMed: 21500258]

19. Rane SD, Gore JC. Measurement of T1 of human arterial and venous blood at 7T. Magn Reson Imaging. 2013; 31:477-9. [PubMed: 23102945]

20. Shimada K, Nagasaka T, Shidahara M, Machida Y, Tamura H. In vivo measurement of longitudinal relaxation time of human blood by inversion-recovery fast gradient-echo MR imaging at 3T. Magn Reson Med Sci. 2012; 11:265-71. [PubMed: 23269013]

21. Thulborn KR, Waterton JC, Matthews PM, Radda GK. Oxygenation Dependence of the Transverse Relaxation Time of Water Protons in Whole Blood at High Field. Biochim Biophys Acta. 1982; 714:265-270. [PubMed: 6275909]

22. Varela M, Hajnal JV, Petersen ET, Golay X, Merchant N, Larkman DJ. A method for rapid in vivo measurement of blood T1. NMR Biomed. 2011; 24:80-8. [PubMed: 20669148]

23. De Vis JB, Hendrikse J, Groenendaal F, de Vries LS, Kersbergen KJ, Benders MJNL, Petersen ET. Impact of neonate haematocrit variability on the longitudinal relaxation time of blood: Implications for arterial spin labelling MRI. NeuroImage Clin. 2014; 4:517-525. [PubMed: 24818078]

24. Wu WC, Jain V, Li C, Giannetta M, Hurt H, Wehrli FW, Wang DJJ. In vivo venous blood T1 measurement using inversion recovery true-FISP in children and adults. Magn Reson Med. 2010; 64:1140-7. [PubMed: 20564586]

25. Zhang X, Petersen ET, Ghariq E, De Vis JB, Webb aG, Teeuwisse WM, Hendrikse J, van Osch MJP. In vivo blood T1 measurements at 1.5 T, 3 T, and 7 T. Magn Reson Med. 2012; 70:10821086. [PubMed: 23172845]

26. Janick P, Hackney D, Grossman R, Asakura T. MR Imaging Various Oxidation States of Intracellular and Extracellular Hemoglobin. Am J Neuroradiol. 1991; 12:891-897. [PubMed: 1950918]

27. Meyer M-E, Yu O, Eclancher B, Grucker D, Chambron J. NMR relaxation rates and blood oxygenation level. Magn Reson Med. 1995; 34:234-241. [PubMed: 7476083]

28. Silvennoinen MJ, Kettunen MI, Kauppinen RA. Effects of hematocrit and oxygen saturation level on blood spin-lattice relaxation. Magn Reson Med. 2003; 49:568-71. [PubMed: 12594761]

29. Rooney WD, Johnson G, Li X, Cohen ER, Kim S-G, Ugurbil K, Springer CS. Magnetic field and tissue dependencies of human brain longitudinal $1 \mathrm{H} 2 \mathrm{O}$ relaxation in vivo. Magn Reson Med. 2007; 57:308-18. [PubMed: 17260370]

30. Uthman, E. Understanding anemia (understanding health and sickness series). University Press of Mississippi; 1998.

31. Hayman LA, Taber KH, Ford JJ, Bryan RN. Mechanisms of MR signal alteration by acute intracerebral blood: old concepts and new theories. AJNR Am J Neuroradiol. 12:899-907. [PubMed: 1950919]

32. Aime S, Fasano M, Paoletti S, Arnelli A, Ascenzi P. NMR relaxometric investigation on human methemoglobin and fluoromethemoglobin. An improved quantitative in vitro assay of human methemoglobin. Magn Reson Med. 1995; 33:827-31. [PubMed: 7651120]

33. Eisenstadt M. NMR relaxation of protein and water protons in methemoglobin solutions. Biophys J. 1981; 33:469-74. [PubMed: 7225516]

34. Bradley WG, Schmidt PG. Effect of methemoglobin formation on the MR appearance of subarachnoid hemorrhage. Radiology. 1985; 156:99-103. [PubMed: 4001427]

35. Day RW, White KS, Hedlund GL. Nitric oxide increases the signal intensity of the T1-weighted magnetic resonance image of blood. J Cardiovasc Magn Reson. 2005; 7:667-669. [PubMed: 16136856]

36. Koenig S, Brown R, Lindstrom T. Interactions of solvent with the heme region of methemoglobin and fluoro-methemoglobin. Biophys J. 1981; 34:397-408. [PubMed: 6264989]

37. Nummi P, Alanen A, Näntö V, Kormano M. Effect of hemolysis and clotting on proton relaxation times of blood. Acta Radiol Diagn (Stockh). 27:225-30. [PubMed: 2424275]

38. Safo MK, Abraham DJ. The X-ray structure determination of bovine carbonmonoxy hemoglobin at 2.1 A resoultion and its relationship to the quaternary structures of other hemoglobin crystal froms. Protein Sci. 2001; 10:1091-9. [PubMed: 11369847] 
39. Benga G, Borza T. Diffusional water permeability of mammalian red blood cells. Comp Biochem Physiol B Biochem Mol Biol. 1995; 112:653-9. [PubMed: 8590380]

40. Jikuya T, Tsutsui T, Shigeta O, Sankai Y, Mitsui T. Species differences in erythrocyte mechanical fragility: Comparison of human, bovine, and ovine cells. ASAIO J. 1998; 44:452.

41. Zhao JM, Clingman CS, Närväinen MJ, Kauppinen Ra, van Zijl PCM. Oxygenation and hematocrit dependence of transverse relaxation rates of blood at 3T. Magn Reson Med. 2007; 58:592-7. [PubMed: 17763354]

42. Zaharchuk G, Martin AJ, Rosenthal G, Manley GT, Dillon WP. Measurement of cerebrospinal fluid oxygen partial pressure in humans using MRI. Magn Reson Med. 2005; 54:113-21. [PubMed: 15968660]

43. Medical, R. The blood gas handbook. Denmark: Radiometer Medical; 2011.

44. Kokholm G. Simultaneous measurements of blood pH, pCO2, pO2 and concentrations of hemoglobin and its derivates-a multicenter study. Scand J Clin Lab Invest Suppl. 1990; 203:75-86. [PubMed: 2128562]

45. Zhou J, Mori S, van Zijl PCM. FAIR excluding radiation damping (FAIRER). Magn Reson Med. 1998; 40:712-719. [PubMed: 9797154]

46. Bloembergen N, Pound R. Radiation damping in magnetic resonance experiments. Phys Rev. 1954; 95:8-12.

47. Zimmerman JR, Brittin WE. Nuclear magnetic resonance studies in multiple phase systems: lifetime of a water molecule in an adsorbing phase on silica gel. J Phys Chem. 1967; 61:13281333.

48. McLaughlin A, Leigh J. Relaxation times in systems with chemical exchange: Approximate solutions for the nondilute case. J Magn Reson. 1973; 9:296-304.

49. Spees WM, Yablonskiy DA, Oswood MC, Ackerman JJH. Water Proton MR Properties of Human Blood at 1.5 Tesla_: Magnetic Susceptibility, T1, T2, T*2, and Non-Lorentzian Signal Behavior. Magn Reson Med. 2001; 45:533-542. [PubMed: 11283978]

50. Silvennoinen MJ, Clingman CS, Golay X, Kauppinen RA, van Zijl PCM. Comparison of the dependence of blood R2 and R2* on oxygen saturation at 1.5 and 4.7 Tesla. Magn Reson Med. 2003; 49:47-60. [PubMed: 12509819]

51. Kageyama K, Onoyama Y, Kogawa H, Goto E, Tanabe K. The maximum and minimum water content and cell volume of human erythrocytes in vitro. Biophys Chem. 1989; 34:79-82. [PubMed: 2611342]

52. Klotz IM. Protein hydration and behavior: many aspects of protein behavior can be interpreted in terms of frozen water of hydration. Science. 1958; 128:815-822. [PubMed: 13592259]

53. Koenig SH, Schillinger WE. Nuclear magnetic relaxation dispersion in protein solutions. I. Apotransferrin. J Biol Chem. 1969; 244:3283-9. [PubMed: 5792660]

54. Nandi N, Bagchi B. Dielectric Relaxation of Biological Water. J Phys Chem B. 1997; 101:1095410961.

55. Otting G, Liepinsh E. Protein hydration viewed by high-resolution NMR spectroscopy: implications for magnetic resonance image contrast. Acc Chem Res. 1995; 28:171-177.

56. Chanarin, I.; Brozovic, M.; Tidmarsh, E.; Waters, D. Blood and its disease. New York: Churchill Livingstone; 1984.

57. Rhoades, RA.; Bell, DR. Medical phisiology: principles for clinical medicine. 4. Wolters Kluwer; 2008.

58. Adair GS, Adair ME. The density increments of proteins. Proc R Soc Lond A Math Phys Sci. 1947; 190:341-56. [PubMed: 20260844]

59. Lentner Co. Ciba-Geigy. Geigy Scientific Tables, Vol 3: Physical Chemistry Composition of Blood, Hematology Somatometric Data. 1985.

60. Fanelli A, Antonini E, Caputo A. Hemoglobin and myoglobin. Adv Protein Chem. 1964; 19:73222. [PubMed: 14268787]

61. Eaton WA, Henry ER, Hofrichter J, Mozzarelli A. Is cooperative oxygen binding by hemoglobin really understood. Nat Struct Mol Biol. 1999; 6:351-358. 
62. Imai K. Adair fitting to oxygen equilibrium curves of hemoglobin. Methods Enzymol. 1994; 232:559-576. [PubMed: 8057879]

63. Johnson CR, Ownby DW, Gill SJ, Peters KS. Oxygen binding constants and stepwise enthalpies for human and bovine hemoglobin at pH 7.6. Biochemistry. 1992; 31:10074-10082. [PubMed: 1390765]

64. Klotz IM. Hemoglobin-oxygen equilibria: retrospective and phenomenological perspective. Biophys Chem. 2003; 100:123-9. [PubMed: 12646358]

65. Freed JH. Dynamic effects of pair correlation functions on spin relaxation by translational diffusion in liquids. II. Finite jumps and independent T1 processes. J Chem Phys. 1978; 68:4034-4037.

66. Bennett HF, Brown RD, Koenig SH, Swartz HM. Effects of nitroxides on the magnetic field and temperature dependence of 1/T1 of solvent water protons. Magn Reson Med. 1987; 4:93. [PubMed: 3031423]

67. Gupta RK, Mildvan AS. Nuclear relaxation studies on human methemoglobin. Observation of cooperativity and alkaline Bohr effect with inositol hexaphosphate. J Biol Chem. 1975; 260:240.

68. Koenig SH, Brown D, Brown RD. Relaxation of solvent protons by paramagnetic ions and its dependence on magnetic field and chemical environment: implications for NMR imaging. Magn Reson Med. 1984; 1:478-95. [PubMed: 6571571]

69. Davidson N, Gold R. The nuclear magnetic relaxation time of water protons in ferrihemoglobin solutions. Biochim Biophys Acta. 1957; 26:370-3. [PubMed: 13499374]

70. Pifat G, Marici S, Grandja S. A proton magnetic relaxation study of human ferrihaemoglobin in aqueous salt solutions. Biopolymers. 1973; 12:905-20. [PubMed: 4695684]

71. Hoffman R, Furie B, McGlave P, Silberstein, Leslie E, Shattil SJ, Benz EJJ, Heslop H. Normal blood values: selected reference values for neonatal, pediatric, and adult populations. Hematology: Basic Principles and Practice. 2008

72. Lu H, Golay X, van Zijl PCM. Intervoxel heterogeneity of event-related functional magnetic resonance imaging responses as a function of T(1) weighting. Neuroimage. 2002; 17:943-55. [PubMed: 12377168]

73. Van Slyke DD, Hiller A, Weisiger J, Cruz W. Determination of carbon monoxide in blood and of total and active hemoglobin by carbon monoxide capacity; inactive hemoglobin and methemoglobin contents of normal human blood. J Biol Chem. 1946; 166:121-48. [PubMed: 20273682]

74. Gibbs E, Lennox W, Nims L, Gibbs F. Arterial and cerebral venous blood: arterial-venous differences in man. J Biol Chem. 1942; 144:325-332.

75. Jain V, Langham MC, Wehrli FW. MRI estimation of global brain oxygen consumption rate. J Cereb Blood Flow Metab. 2010; 30:1598-607. [PubMed: 20407465]

76. Lu H, Hua J, van Zijl PCM. Noninvasive functional imaging of cerebral blood volume with vascular-space-occupancy (VASO) MRI. NMR Biomed. 2013; 26:932-48. [PubMed: 23355392]

77. Alsop DC, Detre JA, Golay X, et al. Recommended implementation of arterial spin-labeled perfusion MRI for clinical applications: A consensus of the ISMRM perfusion study group and the European consortium for ASL in dementia. Magn Reson Med. 2015; 73:102-116. [PubMed: 24715426]

78. Herbst MD, Goldstein JH. A review of water diffusion measurement by NMR in human red blood cells. Am J Physiol. 1989; 256:1097-1104.

79. Stetson CA. The state of hemoglobin in sickled erythrocytes. J Exp Med. 1966; 123:341-6. [PubMed: 5905245]

80. Finch JT, Perutz MF, Bertles JF, Döbler J. Structure of sickled erythrocytes and of sickle-cell hemoglobin fibers. Proc Natl Acad Sci U S A. 1973; 70:718-22. [PubMed: 4123689] 
a)

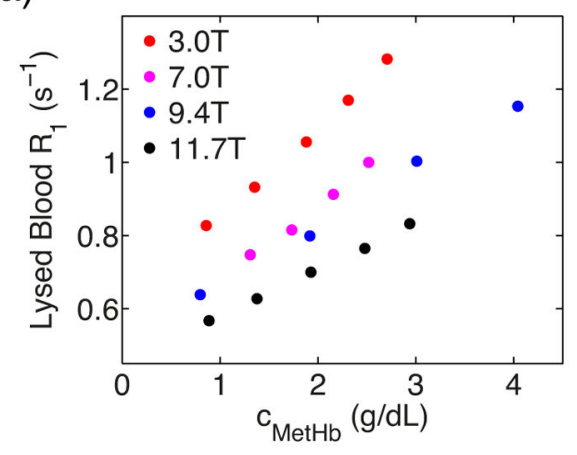

b)

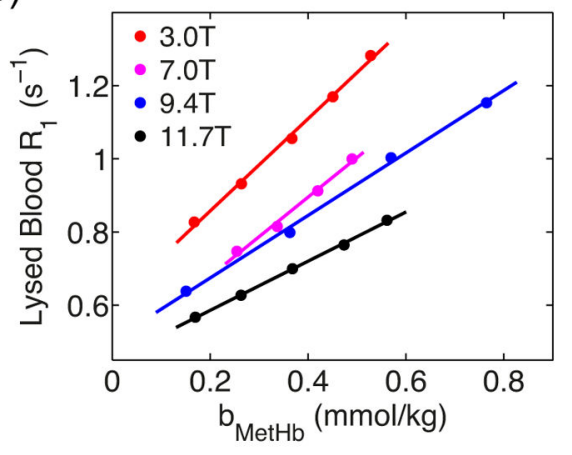

Figure 1.

a) The dependence of lysed blood $R_{1}$ values on the methemoglobin's concentration. $b$ ) Linear fitting of lysed blood $\mathrm{R}_{1}$ values as a function of methemoglobin's concentration under fully oxygenated conditions. 
a)

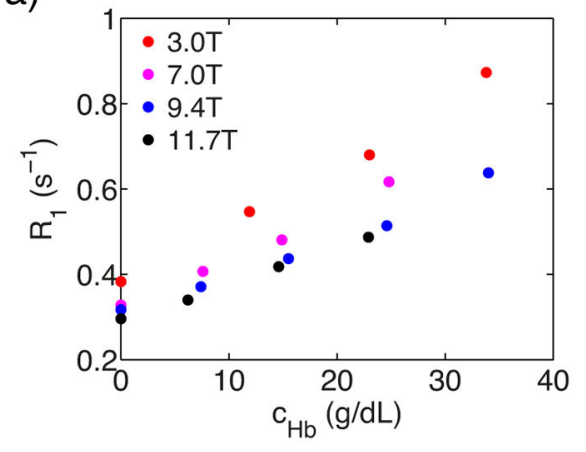

b)

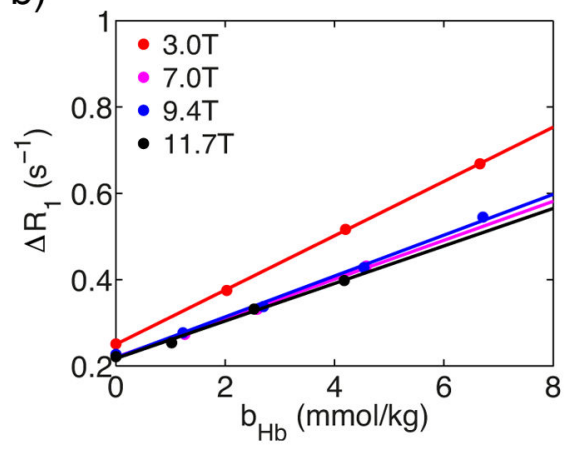

Figure 2.

a) The dependence of lysed blood $R_{1}$ values on the hemoglobin's concentration. $b$ ) Linear fitting of the corrected lysed blood relaxation rate $\Delta \mathrm{R}_{1}$ as a function of hemoglobin's molality concentration at fully oxygenated conditions. 


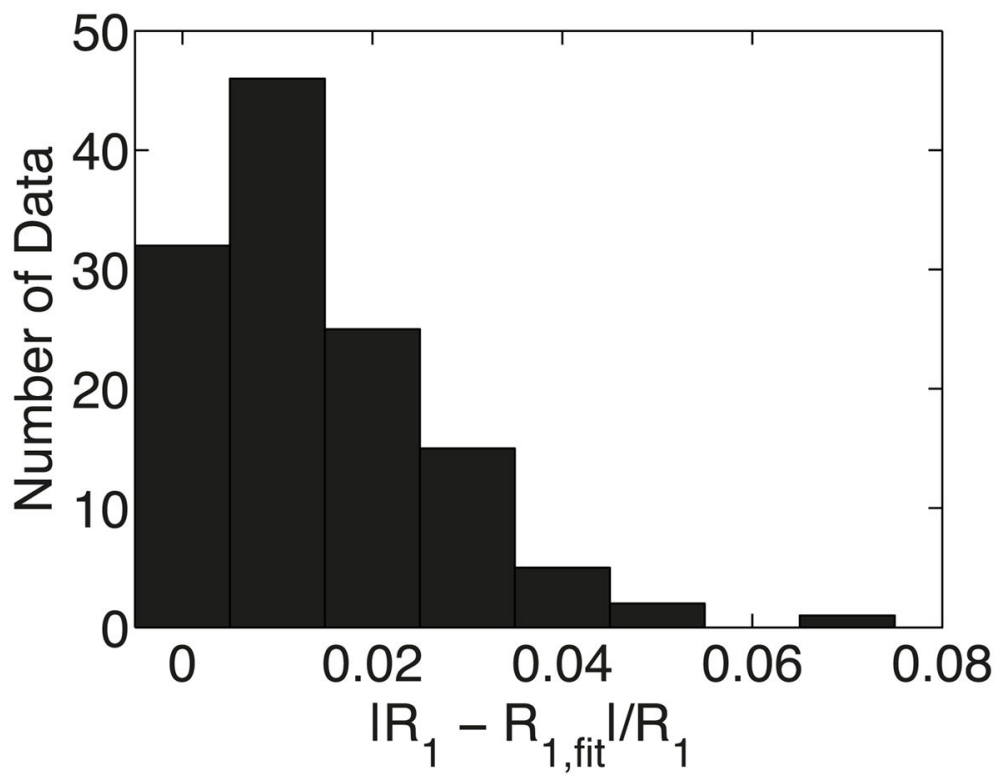

Figure 3.

Histogram summarizing the relative errors between the experimental whole blood $\mathrm{R}_{1}$ and fitted $\mathrm{R}_{1}$. 
a)

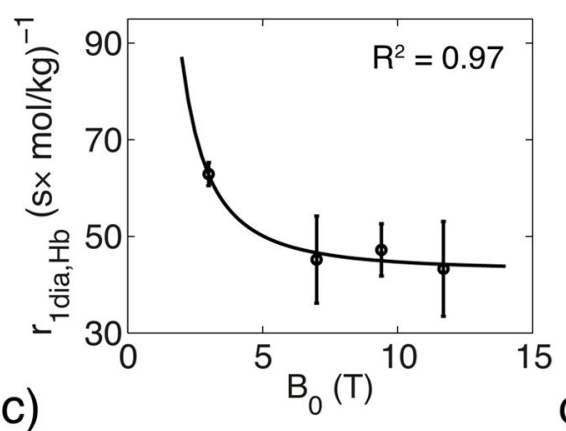

c)

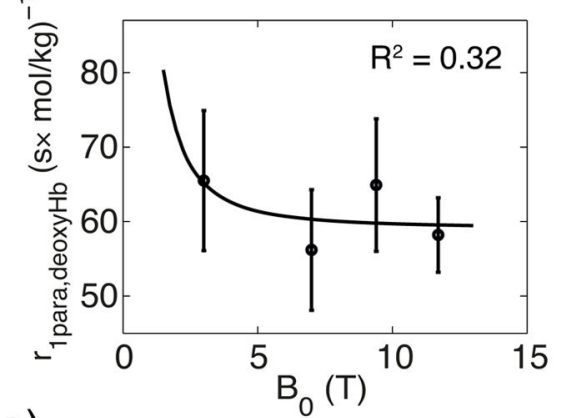

e)

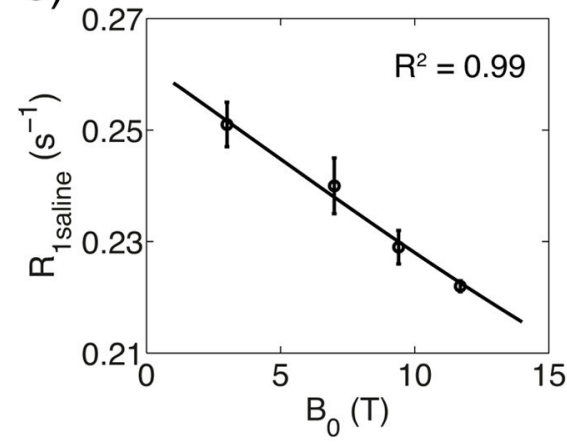

b)
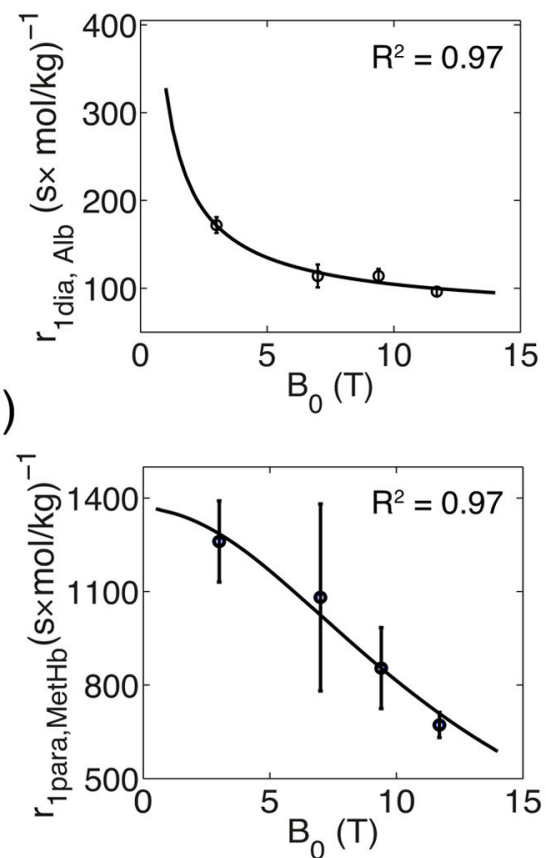

Figure 4.

The magnetic field dependence of $r_{1 \text { dia,Hb }}(a), r_{1 \text { dia,Alb }}(b), r_{1 \text { para,deoxyHb }}(c) r_{1 \text { para,MetHb }}(d)$ and $\mathrm{R}_{1 \text { saline }}(\mathrm{e})$, and numerical fitting using Freed's equation $(65,66)$ (paramagnetic relaxivity, solid line) and Lindstrom and Koenig's Equation (16) (diamagnetic relaxivity and $\mathrm{R}_{1 \text { saline}}$, solid line) 


\section{Table 1}

Fitted paramagnetic relaxivities of methemoglobin and deoxyhemoglobin, diamagnetic relaxivities of albumin and hemoglobin, and relaxation rate of saline, with error indicating $95 \%$ confidence interval of fitting.

\begin{tabular}{lcccc}
\hline $\mathbf{B}_{\mathbf{0}}(\mathbf{T})$ & $\mathbf{3 . 0}$ & $\mathbf{7 . 0}$ & $\mathbf{9 . 4}$ & $\mathbf{1 1 . 7}$ \\
\hline $\mathrm{r}_{1 \text { para,MetHb }} / \mathbf{1 0}^{\mathbf{3}}(\mathrm{mol} / \mathrm{kg \times s})^{-1}$ & $1.26+/-0.13$ & $1.08+/-0.30$ & $0.854+/-0.13$ & $0.672+/-0.040$ \\
$\mathrm{r}_{1 \mathrm{dia}, \mathrm{Alb}}(\mathrm{mol} / \mathrm{kg \times s})^{-1}$ & $172+/-9$ & $114+/-13$ & $114+/-8$ & $96.2+/-5.2$ \\
$\mathrm{r}_{1 \mathrm{dia}, \mathrm{Hb}}(\mathrm{mol} / \mathrm{kg} \times \mathrm{s})^{-1}$ & $62.9+/-2.4$ & $45.1+/-9.1$ & $47.2+/-5.4$ & $43.3+/-9.9$ \\
$\mathrm{r}_{\text {lpara,deoxyHb }}(\mathrm{mol} / \mathrm{kg \times s})^{-1}$ & $65.6+/-8.8$ & $56.2+/-8.1$ & $64.9+/-8.9$ & $58.2+/-5.0$ \\
$\mathrm{R}_{1, \text { saline }}\left(\mathrm{s}^{-1}\right)$ & $0.287+/-0.009$ & $0.263+/-0.007$ & $0.232+/-0.007$ & $0.235+/-0.004$ \\
\hline
\end{tabular}




\section{Table 2}

Measured longitudinal relaxation rates of plasma and saline solution at $37^{\circ} \mathrm{C}$ with error indicating $95 \%$ confidence interval in the fitting of inversion-recovery curves.

\begin{tabular}{lcccc}
\hline $\mathbf{B}_{\mathbf{0}}(\mathbf{T})$ & $\mathbf{3 . 0}$ & $\mathbf{7 . 0}$ & $\mathbf{9 . 4}$ & $\mathbf{1 1 . 7}$ \\
\hline $\mathrm{R}_{\text {1plasma }}\left(\mathrm{s}^{-1}\right)$ & $0.383+/-0.003$ & $0.328+/-0.005$ & $0.318+/-0.003$ & $0.296+/-0.003$ \\
$\mathrm{R}_{\text {1saline }}\left(\mathrm{s}^{-1}\right)$ & $0.251+/-0.004$ & $0.240+/-0.005$ & $0.229+/-0.003$ & $0.222+/-0.001$ \\
\hline
\end{tabular}




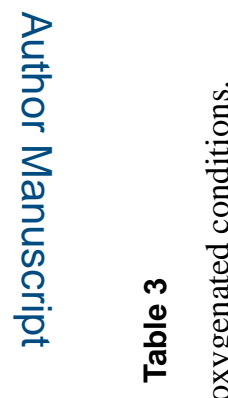

ב

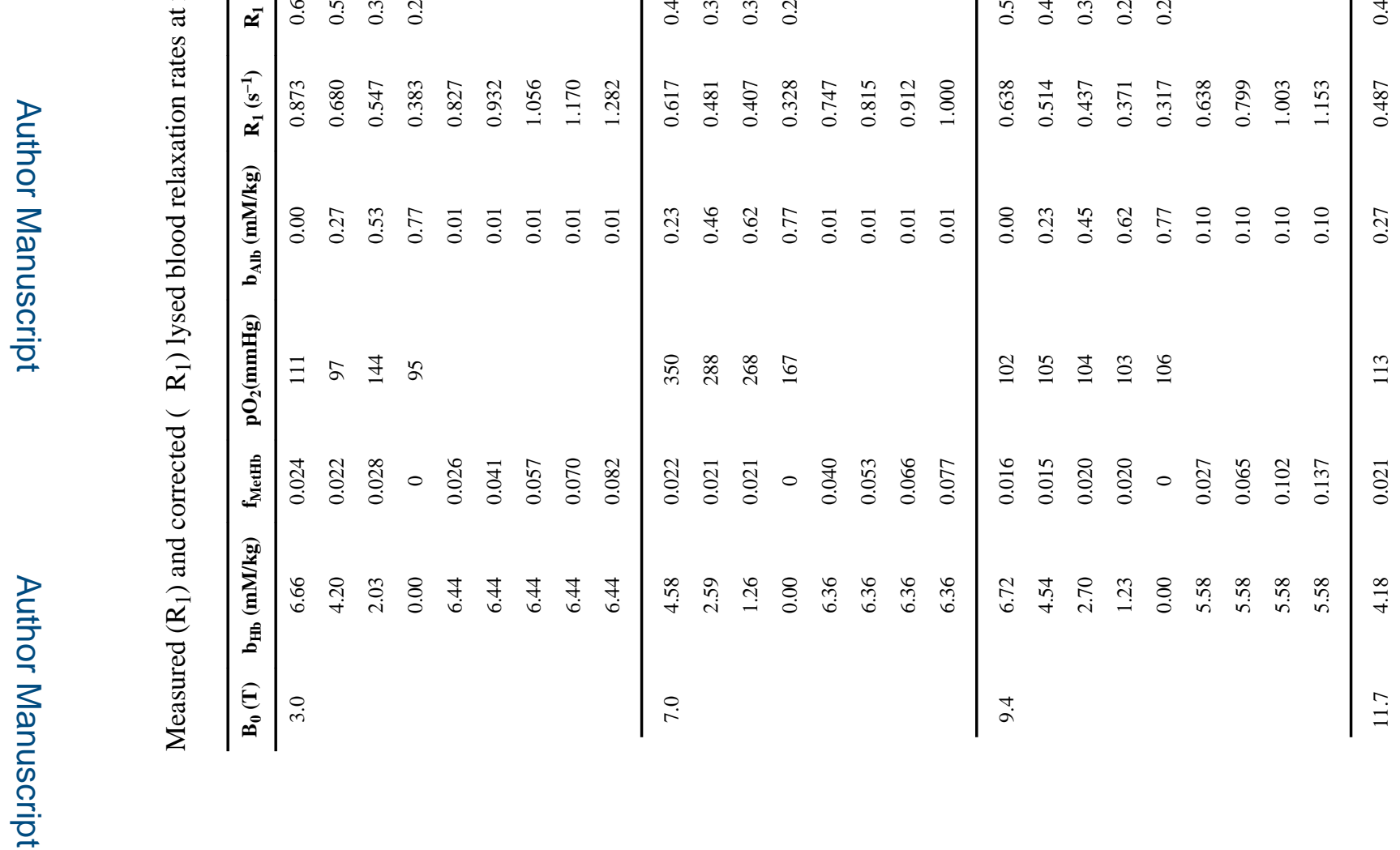

Magn Reson Med. Author manuscript; available in PMC 2017 July 01. 
Li et al.

Page 24

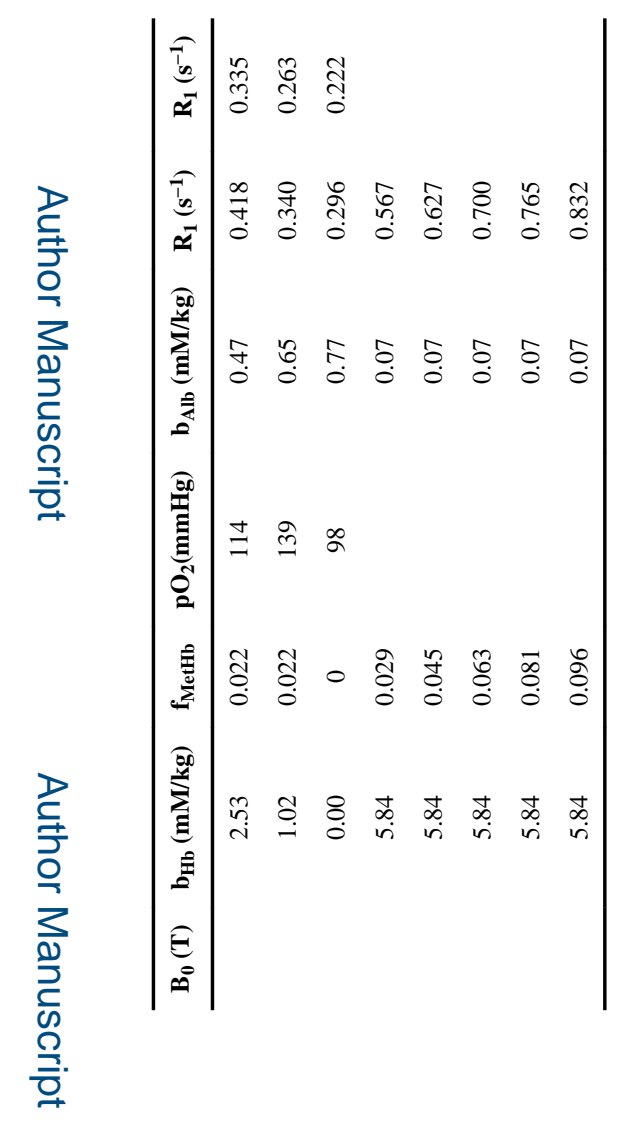

로을

를

Magn Reson Med. Author manuscript; available in PMC 2017 July 01. 


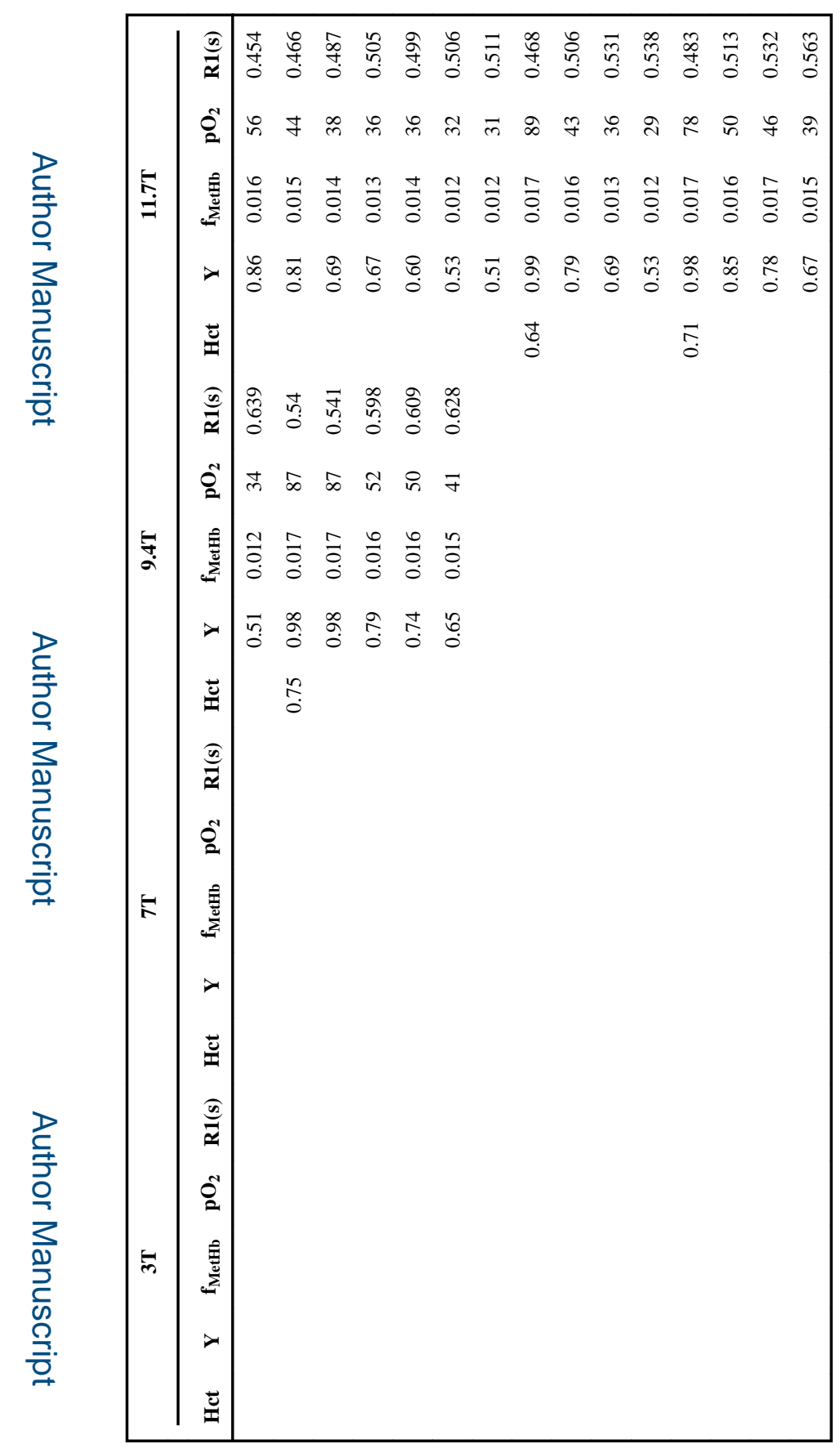

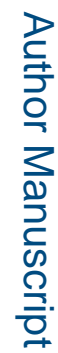

Magn Reson Med. Author manuscript; available in PMC 2017 July 01. 


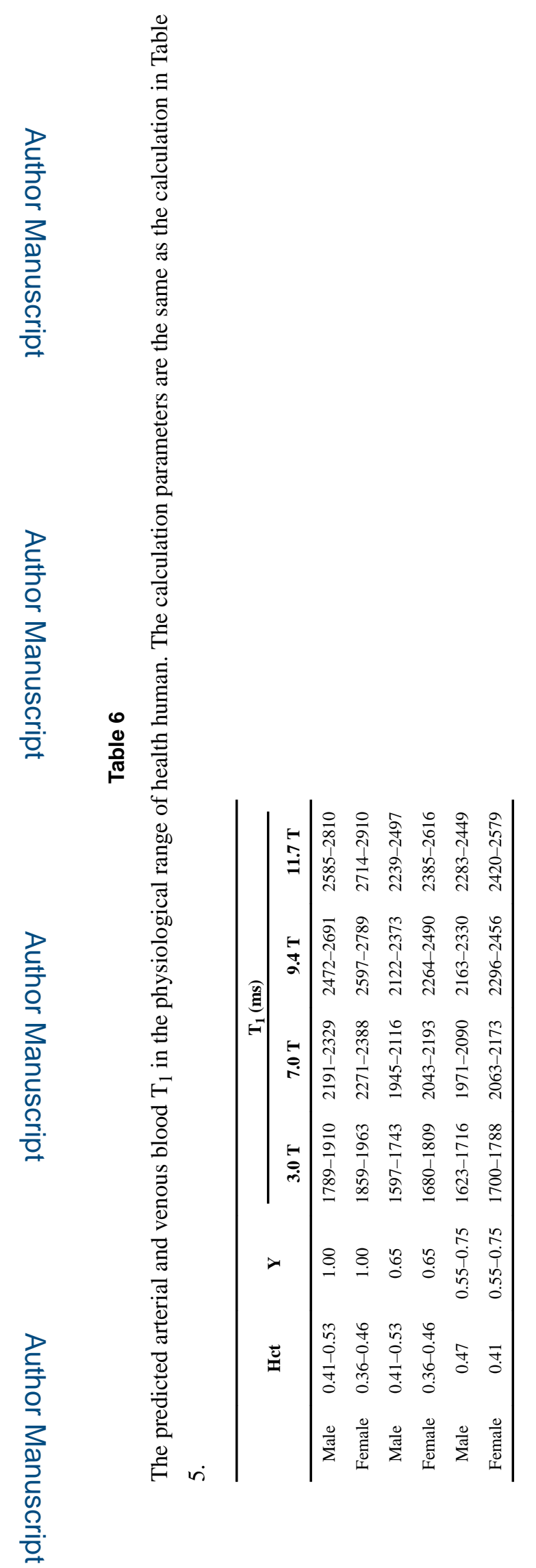

Magn Reson Med. Author manuscript; available in PMC 2017 July 01. 